\title{
Steroidogenic Factor 1
}

National Cancer Institute

\section{Source}

National Cancer Institute. Steroidogenic Factor 1. NCI Thesaurus. Code C75873.

Steroidog enic factor 1 (461 aa, $\sim 52 \mathrm{kDa}$ ) is encoded by the human NR5A1 gene. This protein plays a role in the activation of transcription of steroidogenic genes. 